\title{
Sistemas constructivos en la tipología doméstica de la época virreinal en las ciudades de León y Granada, Nicaragua: arquitectura con valor tecnológico-popular.
}

\section{Construction systems in the domestic typology of the viceregal period in the cities of León and Granada, Nicaragua: architecture with technological- popular value.}

\author{
Estrada-Castillo, Alicia Auxiliadora ${ }^{1}$ \\ ${ }^{1}$ Arquitecta e investigadora independiente, León, Nicaragua \\ 1aliciaestrada.arq@gmail.com / https://orcid.org/0000-0001-8256-8860
}

Recibido el 10 de febrero de 2021, aprobado el 22 de junio de 2021

\begin{abstract}
RESUMEN | El adobe, taquezal y albardeado, reconocidos sistemas constructivos tradicionales fueron introducidos en la época virreinal en el Nuevo Mundo, suponiendo un hibridismo tecnológico entre las poblaciones nativas y las españolas, a través de la materialización de modelos de tipologías arquitectónicas indispensables como la vivienda. Estas nacientes células domésticas junto a regulaciones urbanísticas del Viejo Mundo, adaptadas a las determinantes del medio natural, fueron definiendo a lo largo de siglos el paisaje cultural de la mayoría de asentamientos humanos en la región del pacífico y centro de Nicaragua, con predominante acervo de exponentes en León en su segundo lugar de fundación y Granada; ciudades primigenias de la conquista española en el siglo XVI. Asimismo, las técnicas y habilidades adquiridas en el tequio de la construcción y sus oficios derivados, permitieron la selección y explotación de materia prima vernácula manifestada en la calidad constructiva de la llamada arquitectura colonial doméstica y su evolución espacial, funcional y estilística. Su sobrevivencia a eventualidades naturales, bélicas y demandas sociales contemporáneas, se debe a la identidad colectiva, los bajos costos, aprendizaje y reaprendizaje de los modelos. Aunque parte de este patrimonio cultural inmueble ha persistido en los últimos siglos, es amenazado por obras nuevas y los cambios de usos de suelos, que suponen alteraciones formales-espaciales y demoliciones parciales o totales, actuando en detrimento de su integridad y autenticidad. Sus valores tecnológicos-populares por conocimientos constructivos que han sido objeto de mención y estudio por diversos autores desde la época virreinal, independentista y contemporánea, revelan la importancia de conservar sus atributos para ser heredadas a las futuras generaciones. No obstante, para ello es primordial la sensibilización patrimonial y la formación profesional vinculado a un marco legal competente sobre la atención de estas singulares viviendas integrantes del vasto patrimonio cultural de la nación.
\end{abstract}

PALABRAS CLAVE | Sistemas constructivos tradicionales, patrimonio cultural, arquitectura doméstica, época virreinal, valores culturales, León-Nicaragua, Granada-Nicaragua 


\begin{abstract}
The adobe, taquezal and albardeado, recognized traditional construction systems, were introduced in the viceregal era in the New World, representing a technological hybridism between the native populations and the Spanish, through the materialization of models of indispensable architectural typologies such as housing. These nascent domestic cells together with urban planning regulations of the Old World, adapted to the determinants of the natural environment, were defining over the centuries the cultural landscape of most human settlements in the Pacific region and central Nicaragua, with a predominant collection of exponents in Leon in its second place of foundation and Granada; original cities of the Spanish conquest in the sixteenth century. Likewise, the techniques and skills acquired in the tequio of construction and its derived trades, allowed the selection and exploitation of vernacular raw material manifested in the constructive quality of the so-called domestic colonial architecture and its spatial, functional and stylistic evolution. Its survival to natural and war eventualities and contemporary social demands is due to the collective identity, low costs, learning and relearning of the models. Although part of this immovable cultural heritage has persisted in the last centuries, it is threatened by new works and changes in land use, which involve formal-spatial alterations and partial or total demolitions, acting to the detriment of its integrity and authenticity. Its technological-popular values for constructive knowledge that have been the subject of mention and study by various authors since the viceroyalty, independence and contemporary times, reveal the importance of preserving its attributes to be inherited to future generations. However, in order to do so, it is essential to raise heritage awareness and professional training linked to a competent legal framework on the care of these unique dwellings, which are part of the vast cultural heritage of the nation.
\end{abstract}

KEYWORD | Traditional construction systems, cultural heritage, domestic architecture, viceregal period, cultural values, León-Nicaragua, Granada-Nicaragua

\title{
1. Introducción
}

La colonización española en los territorios del Nuevo Mundo responde a una idea universal de imperio, liderado por la Monarquía española con gran apoyo de la Iglesia Católica, promovidos principalmente por factores comerciales y obtención de metales preciosos, que los condujo a un territorio inesperado como parte de las exploraciones del navegante genovés Cristóbal Colón. Este proceso militar y de adoctrinamiento se colmó de pactismos entre los exploradores, materializado en el reparto de tierras y nativos como parte de la encomienda, la evangelización de los naturales como tarea de las órdenes religiosas introducidas y la fundación de ciudades complementadas con incursiones tecnológicas extranjeras como la rueda, establecimiento de la actividad ganadera, cosechas de nuevos alimentos e insumos, entre otros elementos que suponen a su manera una etapa de globalización incipiente con una injustificable violación de derechos humanos de los invadidos.

A inicios de este período histórico, Nicaragua figuraba como una provincia con ciudades fundadas tempranamente en el continente americano. León y Granada fueron establecidas en 1524 y el fin de esta etapa ha sido fechada en 1821 con la firma del Acta de la Independencia de América Central en el entonces Reino de Guatemala, pero consumada en años posteriores. El asentamiento de ciudades y villas correspondieron a lineamientos y ordenanzas que se fueron perfeccionando 
a lo largo del reinado español en América. Evidentemente, la conformación de las nuevas urbes, próximas a territorios aborígenes requirieron con prontitud el trazado de plazas, templos, cabildos, fortalezas y por supuesto, el espacio donde se desarrollaría la vida cotidiana de los nuevos vecinos españoles: su arquitectura doméstica.

Estas primigenias tipologías ajenas al prototipo de los hogares de los nativos, incurrieron en la implementación de materiales vernáculos con el empleo de su mano de obra, quienes, por obediencia al Requerimiento, aplicaron técnicas constructivas incipientes que propiciaran a lo inmediato las condiciones de poblamiento para la naciente sociedad. Con el transcurso del tiempo y según el progreso de los centros urbanos, esta tipología experimentó una evolución en proporciones, durabilidad, espacialidad y confort ambiental, gracias a las propiedades de los sistemas constructivos hoy reconocidos como tradicionales, los cuales han sucumbido en innumerables episodios bélicos y ante fenómenos naturales, pero reconstruidos gracias a los saberes tradicionales adquiridos en los años próximos a la época en los oficios de albañilería y carpintería, el fácil acceso a materia prima $\mathrm{y}$ al valor tecnológico popular que se fue forjando sin notar intromisión en las formas de vida del colectivo.

No obstante, en la actualidad estas tipologías domésticas persisten bajo la lucha entre la herencia colonial y las necesidades contemporáneas de la sociedad. Estas demandas involucran acciones de alteraciones, destrucción parcial o total de los inmuebles para dar cabida a nuevos usos, agudizado por la introducción de nuevas obras o reformas basadas en materiales contemporáneos no orgánicos a mano de personal no calificado que actúan en detrimento de la integridad de este patrimonio cultural inmueble, ocasionan cambios en la imagen urbana y propician desvinculación en los valores sociales.

Por tanto, el reconocimiento de los valores de la arquitectura habitacional con sistemas constructivos heredados de la época colonial, es un punto de partida para la conservación de sus atributos con vínculos identitarios, los cuales constituyen a su vez el paisaje cultural de muchos pueblos americanos, incluyendo León y Granada como máximos representantes en Nicaragua. El abordaje de la temática central bajo los componentes tipológicos de modelos domésticos, distribución de ambientes, características formales, sistemas constructivos y valores de la vivienda colonial corresponde a un propósito de sensibilización social que aporte a la conservación de la memoria de estos bienes, prácticas y técnicas que han ocupado un lugar en la historia y no merecen su desvinculación con el futuro. Por su enfoque se pretende que esta caracterización general y a su vez comparativa, sea un asunto de interés para los investigadores, arquitectos, urbanistas, restauradores, entre otras disciplinas del ámbito científico y académico.

\section{Metodología}

El legado arquitectónico de la colonia española en la Región del Pacífico y Central del país fue significativo, con mayor peso en la primera. Sin embargo, el área de estudio se limitó a los asentamientos urbanos de relevancia en cuanto a orígenes, desarrollo y acervo de la tipología doméstica. Entre estos figuran el sitio arqueológico Ruinas de León Viejo, León en su segundo lugar de establecimiento y Granada. El primero fue considerado por exponer la arquitectura naciente de un centro urbano con apenas 86 años de existencia sin posterior alteración humana por ocupación; y las siguientes, por reunir significativos repertorios de la tipología habitacional con sistemas tradicionales orgánicos como el adobe, taquezal y albardeado o bahareque con implementaciones de cantería como componente estructural en cimientos y soportes de vanos en puertas y ventanas; y el sistema tradicional pétreo artificial: ladrillo de barro cocido, material cerámico empleado en 
muros aislantes de zonas húmedas, en pisos y su teja criolla en cubiertas.

La investigación es descriptiva, predominantemente cualitativa con recolección de datos mixtos: en campo y de forma documental. Su estudio de corte longitudinal permitió la exploración de 93.46 hectáreas (1,336 edificaciones) del centro histórico de Granada y 253 hectáreas (1,969 edificaciones) del casco histórico de León, cifras obtenidas en los respectivos resúmenes ejecutivos de los planes de revitalización.

Dicha exploración constituye la principal fuente de información primaria y obedece al estudio de la zona en la última década por parte de la autora, a través de su experiencia laboral en la gestión de la Oficina de Centro Histórico de la Alcaldía de Granada y la docencia universitaria en León. Además, recientemente se efectuaron entrevistas a profesionales en arquitectura e historia. Finalmente, entre las fuentes secundarias consultadas datan publicaciones como León Viejo: Pompeya de América, Catálogos de Bienes e Inmuebles de Granada y León, estudios tipológicos y los planes de revitalización de ambos centros históricos, entre otros.

\section{Resultados}

\section{Generalidades de la tipología arquitectónica doméstica en la época virreinal}

La vivienda de la época virreinal tiene sus antecedentes en la Domus Romana, figurando como modelo en la determinación de ambientes: fauces o vestíbulo de acceso en representación del zaguán iberoamericano, atrium o patio interior, peristylum o jardín porticado, culina o cocina entorno al atrium al igual que las cubilas o dormitorios, y el triclinium o comedor (Fernández Vega, 2003). Estas particularidades espaciales junto a elementos decorativos legados por los moros durante el sometimiento de España por los árabes, son el resultado de la llamada vivienda colonial, adaptada por los alarifes españoles y nativos en las ciudades del Nuevo Mundo. Partiendo de estas generalidades, Kubler aclara que "la estructura y forma de las casas rurales españolas están determinadas por la naturaleza del material disponible" (Kubler, 1982, pág. 192); condición imprescindible que favoreció el surgimiento de variantes en composición volumétrica, espacio y estructura de las viviendas de las ciudades del Viejo y Nuevo Mundo. Además, puntualmente refiere que las viviendas implantadas en América corresponden a las casas con patio, de antecedentes moriscos y romanos localizados al sur de España.

El diplomático valenciano Ernesto La Orden Miracle en su obra Catálogo Provisional del Patrimonio Histórico-Artístico de Nicaragua (1971) señala que el influjo cultural en la provincia de Nicaragua provino mayormente del virreinato de Nueva España y la Capitanía General de Guatemala a quien Nicaragua quedó supeditada desde 1570, reconociendo algunas diferencias en sistemas constructivos por la condición sísmica nicaragüense y los recursos particulares de cada territorio.

Para determinar los orígenes de las células domésticas en Nicaragua, es necesario remitirse a los vestigios arqueológicos de la vivienda colonial del primer centro urbano León Viejo1 ${ }^{1}$ o León de Nagrando, fundada en $1524^{2}$ por Francisco Hernández de Córdobas al Noroeste del Lago Xolotlán, en una zona fértil y con numerosa población indígena, en congruencia con una serie de ordenanzas expedidas de España que fueron consolidándose a lo largo del reinado, siendo una de las iniciales

1 El sitio arqueológico Ruinas de León Viejo constituye los vestigios de León Santiago de los Caballeros de Nicaragua en su original lugar de fundación, abandonada en 1610 debido a motivos sociales, económicos y naturales.

2 Existen diferentes posturas sobre la determinación de la fecha exacta de fundación de León y Granada, razón que ha originado una disputa sobre la titulación de primera ciudad colonial española establecida en territorio nacional. 
las correspondientes a la urbanización y trazado, recibida por Pedrarias Dávila en 1513:

Una de las cosas más importantes que deben tenerse en cuenta es... que los lugares elegidos para los emplazamientos sean sanos, no pantanosos; tratándose del interior, a ser posible a lo largo de un río, con agua y aire puro y terreno apto para el cultivo en las proximidades. Una vez hallado un lugar con estas características, deben parcelarse los solares para edificar las casas... y desde el principio deben trazarse de acuerdo con un plano definido, porque la forma de los solares determinará el modelo de la ciudad, tanto en la disposición de la plaza y de la iglesia, como en la dirección de las calles, puesto que las ciudades nuevas pueden fácilmente ser conformadas de acuerdo con un plano. Si al principio no se sigue una forma, no será posible conseguirla después (Instituto Nicaragüense de Cultura [INC], 2014, p. 101).

Este precepto arroja que la importancia de la parcelación conllevó a la determinación de los modelos de las viviendas, y estas al dimensionamiento de las manzanas que favorecieron la morfología urbana tipo damero, propias de León y Granada. López Santiago asevera que las viviendas "tanto en su composición espacial, como en su formación plástica, parecen haber servido a los fines originalmente previstos (1981: 23)" (Instituto Nicaragüense de Cultura [INC], 2014, p. 101). Y Aguilera Rojas manifiesta que la vivienda es un elemento crucial dentro de los trazados urbanos regulares:

Si los edificios religiosos o civiles como iglesias, conventos, hospitales, ayuntamientos, aduanas, casas reales (...) van a singularizar el modelado de la ciudad, la arquitectura doméstica, que constituye la mayor parte de las construcciones levantadas, va a ser el auténtico tejido urbano que dé forma a las ciudades (1994, p. 249).

Es necesario advertir que los esquemas de plantas de viviendas en León Viejo por su condición ruinosa, no muestran la integridad de su concepción original. No obstante, Ernesto La Orden Miracle estima como característica espacial, plantas en casas e iglesias con estructura tipo rural castellano (Catálogo Provisional del Patrimonio Histórico-Artístico de Nicaragua, 1971). Las viviendas analizadas se sitúan sobre la Calle Real, a excepción de la Estructura 6, que se encuentra contiguo a la Casa de Ana Jiménez, pero sobre la vía que dirigía a la fortaleza. Fueron seleccionadas porque permiten una lectura de la organización espacial a través de ambientes, los cuales presentan proporciones regulares con relaciones contiguas predominantemente, y vinculadas a otro espacio común por el patio interno (Casa del Gobernador, Casa de Gonzalo Cano y Casa de Ana Jiménez).

Retomando el caso de la ciudad de Granada, su "Estudio Tipológico Urbano Arquitectónico" reafirma respecto al principio de alineación de fachadas sobre límite de predio que los antecedentes de las células domésticas surgen del lote y a partir de este se proyectarían los ambientes:

La casa en Granada evoluciona a partir de la agrupación de células, que siguiendo los parámetros establecidos por los bordes urbanos de la manzana, consolida primero que todo un frente a la calle, y después define el patio; hasta lograr el grado máximo al establecer una ocupación total del perímetro de la parcela, y definir el carácter centralizado del patio (Oficina de Preservación del Centro Histórico de Granada, 2006, p. 34).

Otra estipulación que quizás responda al sistema de viviendas alineadas, contiguas y paralelas al trazado de calles de León en su segundo sitio es la Ordenanza de Felipe II, la cual dicta en su artículo 133: "dispónganse los edificios de las casas de toda la población, generalmente de manera que sirvan de defensa y fuerza contra los que quisieren atacarla” (Oficina Técnica de 


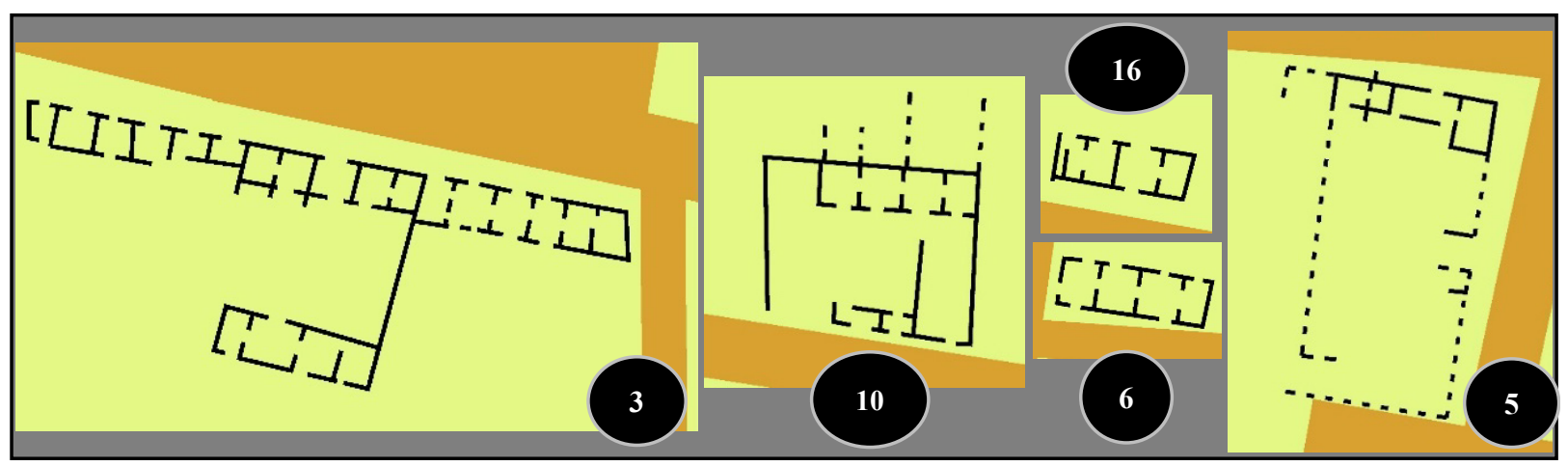

Figura 1: Modelos de viviendas en la primera ciudad de León Santiago de los Caballeros. Casa del gobernador (estructura 3), Casa de Gonzalo Cano (estructura 10), Casa de Hernando de Soto y Hernán Ponce de León (estructura 16), Casa de Ana Jiménez (estructura 5) y estructura no identificada 6. Fuente: Instituto Nicaragüense de Cultura [INC]. Edición propia sin escala.

Gestión del Centro Histórico de León, 2010, p. 102). No obstante, en el pueblo indígena de Sutiava esta distribución difirió en gran manera, ya que los indígenas, estaban acostumbrados a vivir en chozas aisladas y rodeados de áreas verdes. Por tanto, esta normativa materializada en patrón, fue aplicada estrictamente a viviendas de tipología urbana, particularmente para la ciudad de León en su reasentamiento en 1610, en décadas posteriores al surgimiento de dicha norma. Es decir, hasta 1573 las ciudades hispanoamericanas se construyeron sin participación del Consejo de Indias en lo que refiere a las normas urbanísticas (Aguilera Rojas, 1994, p. 109), pero como se mencionaba anteriormente, ya existían ordenanzas que regían este importante lineamiento de la empresa de la Conquista. Por ende, cabe suponer que las primeras ordenanzas establecieron los trazados de parcelas y alineación de viviendas para León Viejo y Granada.

Estos modelos domésticos integraron beneficios de la arquitectura bioclimática que contribuyen significativamente en el modo de vida de sus ocupantes al contrarrestar las sensaciones del clima cálido; un principio de la arquitectura vernácula. Entre las características están el aprovechamiento de ventilación e iluminación natural, a través de la penetración de rayos de sol y el movimiento de flujos de aire en los patios internos, que circulan por diferentes dependencias sociales, de servicio y privadas. Además, las propiedades de reducción de temperatura en los sistemas constructivos de adobe, taquezal, albardeado o bahareque y productos cerámicos derivados del barro al horno, hacen la habitabilidad más confortable. También es importante mencionar la sostenibilidad socioambiental que se producía en estos hogares al cultivar en patios verduras, condimentos, plantas medicinales y alimento para animales de carga. Al respecto, el diplomático estadounidense Ephraim Squier en su obra Nicaragua. Sus gentes y paisajes, señala:

Las casas, al igual que las de Granada son de adobes, y rara es la que tiene más de un piso. Todas tienen un espacioso patio sembrado de árboles frutales o simplemente sombrosos. Algunas tienen también un traspatio, en el fondo de la casa destinado a los animales domésticos, mientras que el inmediato a las habitaciones está plantado de arbustos y rosales, y rodeado de amplios corredores. Este estilo, de construcción muy adecuada al clima y necesario en un país donde los temblores son frecuentes, es de poca presunción arquitectónica. (Oficina Técnica de Gestión del Centro Histórico, 2010, pp. 96-97)

Dentro de sus generalidades por ordenación territorial, la arquitectura habitacional hispanoamericana se categoriza en vivienda urbana y vivienda rural, con subgéneros que difieren según las ciudades. Según Ceballos (2018), palacios, villas, casas y posadas corresponden a la sub 
clasificación de uso doméstico y alojamiento. Diversas fuentes aseguran que Ana Jiménez en León Viejo contaba con un modesto hospedaje para las esposas de los conquistadores, sin embargo es necesario realizar más indagaciones.

De acuerdo a la ubicación, las viviendas de los vecinos españoles se establecían en los predios de las áreas definidas como urbanas por su cercanía a los edificios del aparato político, administrativo y religioso; y en sus inmediaciones se encontraban los barrios de indios. Esta disposición fue cambiando mientras se ocupaban los solares disponibles y la población urbana crecía, de tal manera que propiciaban la expansión de las trazas primitivas. Mientras tanto, estos pueblos de indios fueron devorados, sus viviendas destacaron por el empleo de materiales vernáculos para soluciones arquitectónicas modestas en comparación con los habitantes que ocupaban los centros de los asentamientos. Tales viviendas pueden corresponder a "un tipo muy elemental de arquitectura doméstica de poca superficie, sin edificación alrededor de un patio, de estrecha fachada y con un espacio de desahogo en la trasera del cuerpo edificado" (Aguilera Rojas, 1994, p. 253).

No es debido olvidar el género hacienda. Situadas en las zonas rurales, suelen relacionarse a actividades de producción. Aún en la Región Central de Nicaragua persisten muchos ejemplares de esta tipología, que además de su peculiar arquitectura campestre, fueron ocupadas por personajes vinculados a actividades económicas que supusieron desarrollo local en su momento y conservan valores históricos.

La vivienda urbana rescata las características espaciales del modelo romano antes señalado: habitaciones con escasez de ventanas entorno a un patio interno generalmente tipo claustro, un segundo patio o post-patio separados por otras dependencias de servicio como la cocina (ver figura 2). Algunos modelos por la generosidad del tamaño del lote, presentaron un tercer patio. El zaguán permitía una comunicación directa entre el exterior con los corredores enclaustrados y el área de servicio. Por este mismo acceso ingresaban y salían las carretas, las cuales eran colocadas en el traspatio junto a los animales y pequeñas plantaciones. La vida social se desarrollaba en sus salas y los corredores del patio central (probablemente en el esquema exista un error al no representar comunicación entre el ambiente sala y los corredores del patio central).
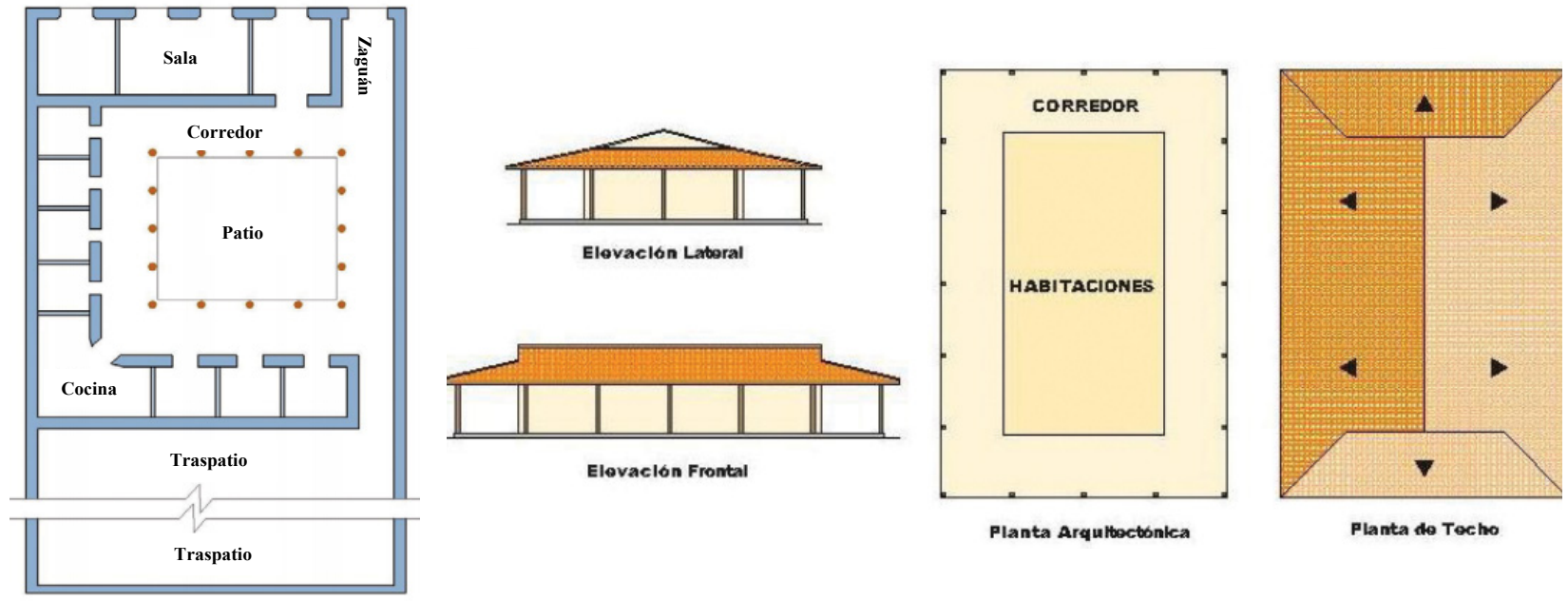

De izquierda a derecha Figura 2: Vivienda colonial según descripción de Squier en su libro Nicaragua. Sus gentes y paisajes. Fuente: Estudio Tipológico Urbano Arquitectónico del Centro Histórico de León, p. 97. Figura 3: Modelo de la vivienda rural. Fuente: Estudio Tipológico del Centro Histórico de León, p. 96. 
En cuanto a la vivienda rural, el Estudio Tipológico Urbano Arquitectónico del Centro Histórico de León (2010) la describe como: "el núcleo central está rodeado de un corredor que se utiliza a lo largo del día según el soleamiento y la dirección de los vientos" (p.96). La vida social se producía en estos largos corredores y la vida privada en la manera de lo posible, se generaba en el interior de la vivienda.

Aguilera Rojas (1994) retoma un interesante hallazgo determinado por los estudios tipológicos y urbanos de Granada en el que señala que la casa urbana tiene sus orígenes en las características espaciales y formales de la casa rural, evolucionando con posterioridad a a la casa-patio y derivación de otras variantes como el segundo patio. Sugiere que estos tres modelos pudieron ser retomados en muchas otras ciudades. En ambas ciudades en estudio hubo similitudes y diferencias marcadas. En cuanto a las divergencias, en Granada se han encontrado modelos de galerías porticadas que comunicaban con la calle en viviendas que no necesariamente colindaban con una plaza, en correspondencia con el modelo de la casa rural planteada por Aguilera Rojas (Casa de las Alemanas, Casa de la Venerable Leytona, Casa El Palenque o Recodo, viviendas del costado oeste de la Iglesia San Francisco, conocidas como Galerías Porticadas de San Francisco, entre otras).

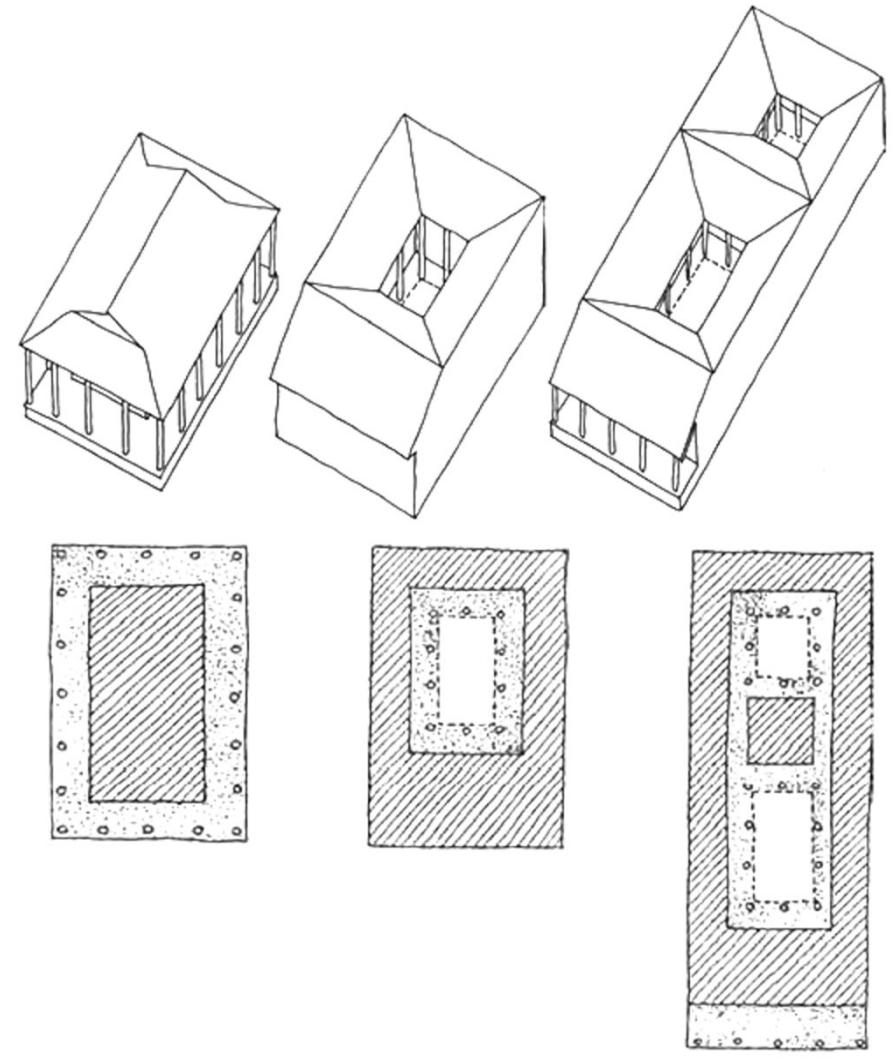

Figura 4: La casa-patio. El amplio corredor o galería de la casa rural se invierte en la casa urbana convirtiéndose en un patio; alrededor del cual se organiza la casa; más tarde aparece el corredor exterior; espacio semipúblico que conecta la casa con la calle; la casa urbana crece hacia el interior de la manzana añadiéndose nuevos patios. Fuente: Aguilera Rojas, J. (1994).

En León predominaban los balcones corridos, eliminados casi en su totalidad en la época independentista por una ordenanza en 1894 conocida como Ley de Ornato, consultada por el historiador Edgardo Buitrago: "deshacer los balcones que daban a la calle, así como las ventanas que salían en cierta medida del frente exterior de las casas, para dar lugar a la construcción de 
aceras corridas, que permitieran la libre circulación de las personas" (Oficina Técnica de Gestión del Centro Histórico, 2010, p. 30). Por ende, esta norma sugiere que las ventanas pata de pollo también sufrieron alteraciones.

Otra notoria diferencia entre las viviendas coloniales granadinas y leonesas radica en las variantes de accesos en esquinas. En Granada predomina la esquina con ochave. León además de presentar esta variante, destaca por la esquina punta de lanza. Se aduce que el modelo leonés pueda tener sus orígenes en las ventanas de ángulo existentes en Extremadura, España (La Orden Miracle, 1971). En fin, estos elementos peculiares merecen estudio particular por su aporte a la estética, utilización del espacio en ambientes esquineros y soluciones constructivas en techo.

En volumetría, las viviendas coloniales marcaron sus inicios con vanos muy reducidos y proporciones de aspecto achaparrado. Probablemente León Viejo hubiera aportado patrones compositivos de las primeras viviendas en Nicaragua, pero justamente, su estado ruinoso no permite su comprobación. A pesar de ello, en León y Granada se conservan casos de viviendas con estas características similares como la poca altura, situadas sorpresivamente entre manzanas con arquitectura doméstica jerárquica, así como en las periferias de los centros históricos. Esta variante recibe el nombre de vivienda colonial popular.
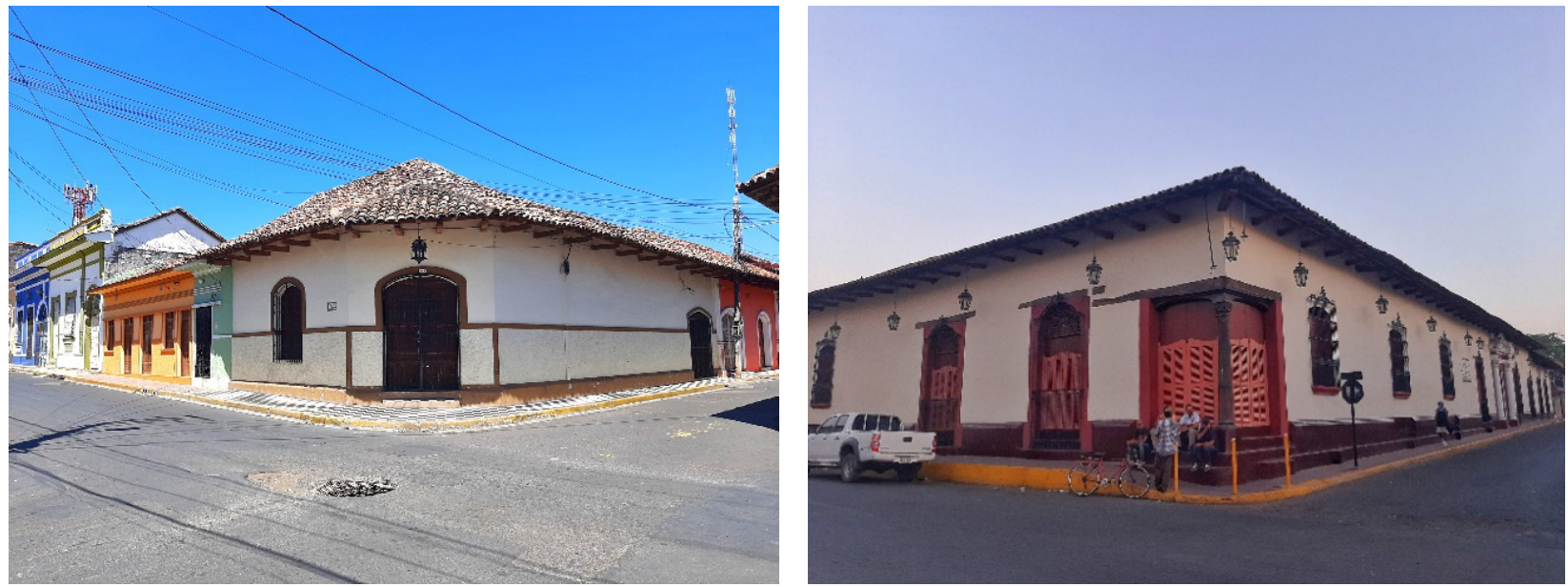

De izquierda a derecha Figura 5: Esquina en chaflán, Granada. Figura 6. Casa Norberto Ramírez, León. Esquina con punta de lanza. Fuente: Propia

La ostentación estilística arquitectónica fue determinada progresivamente por etapas históricas y de acorde a las posiciones sociales de los vecinos españoles, diferenciándose de las demás viviendas por sus sistemas constructivos, proporciones, espacialidad de dependencias, acabados y por supuesto, el desarrollo alcanzado en las urbes. Al respecto, Ephraim Squier expone lo siguiente sobre la casa leonesa, años previos a la Guerra Nacional de 1856:

(...) No da al constructor oportunidad de demostrar su gusto ni su técnica, salvo en el portón o zaguán, y en los balcones enrejados. Los zaguanes son a menudo altos e imponentes, y lucen ornamentados de buen gusto. Algunos reproducen los arcos moriscos tupidos de arabesco tan comunes en España. Otros son de severo estilo griego, y también los hay de diseño indescriptible y claramente original. Sobre estos arcos la vieja aristocracia solía tallar sus blasones, los militares sus escudos de armas, y los inclinados a la piedad de una jaculatoria, o bien, un pasaje de la Biblia (Oficina Técnica de Gestión del Centro Histórico, 2010, p. 97). 
En el siglo XVIII y XIX con la introducción de los estilos extranjeros como el neoclásico y barroco (principalmente en arquitectura religiosa) fue notoria la evolución de las viviendas en cuanto a alturas, decoro y cantidad de niveles que tomaban como punto de partida la planta originaria de la casa. Muestra de ello, son las viviendas de la ciudad de Granada, destruidas casi en su totalidad por la Guerra Nacional de 1856, en donde el sustrato base de la casa con patio persistió, ya que la planta anterior fue utilizada como guía para la edificación de los nuevos inmuebles y continúo de esa forma con los venideros estilos de la época contemporánea. El tequio desempeñó un papel trascendental en estos sucesos bélicos, ya que, desde la época prehispánica como parte del trabajo o tributo, colectivamente se disponían a realizar trabajos de construcción y reparación de su entorno.

Por tanto, formalmente la arquitectura doméstica de la época virreinal que exponen estas

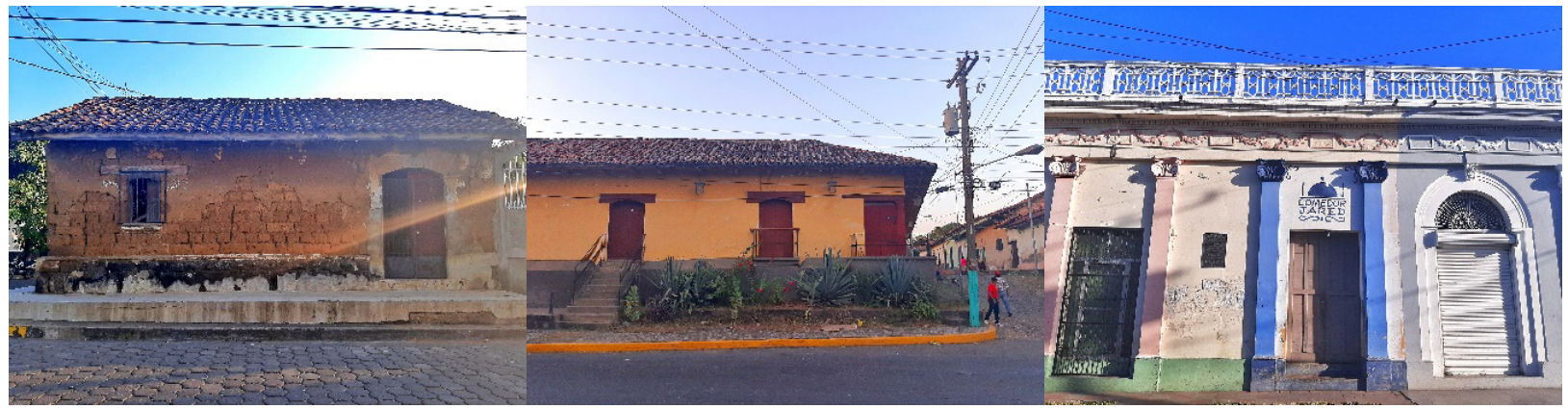

Figura 7: (Leer de izquierda a derecha) Exponentes de vivienda colonial popular en barrio Sutiava, vivienda colonial tradicional en barrio Laborío (conocida como la Casa más Antigua de León según concurso de la Alcaldía en el 2013) y vivienda neoclásica en barrio La Recolección de la ciudad de León. Fuente: Propia.

ciudades obedecen al estilo neoclásico, tendencia colonial tradicional y podría incluirse un tercer grupo denominado arquitectura colonial popular. La primera definió la arquitectura domiciliar de las familias con poder adquisitivo y deseosas de realizar cambios distintivos del colonial original; la segunda exhibe una estética uniforme con claros principios compositivos de limpieza, pero sin abandonar el ostento; y la tercera, demuestra simpleza y difiere en algunos aspectos a la tradicional en cuanto a proporción y reducción de ambientes. Realmente, es un trabajo arduo intentar catalogarlas, ya que existen variedades dentro de cada categoría, sin embargo, en la tabla 1, se trató de recopilar los elementos característicos de cada uno de estos modelos en las ciudades de Granada y León.

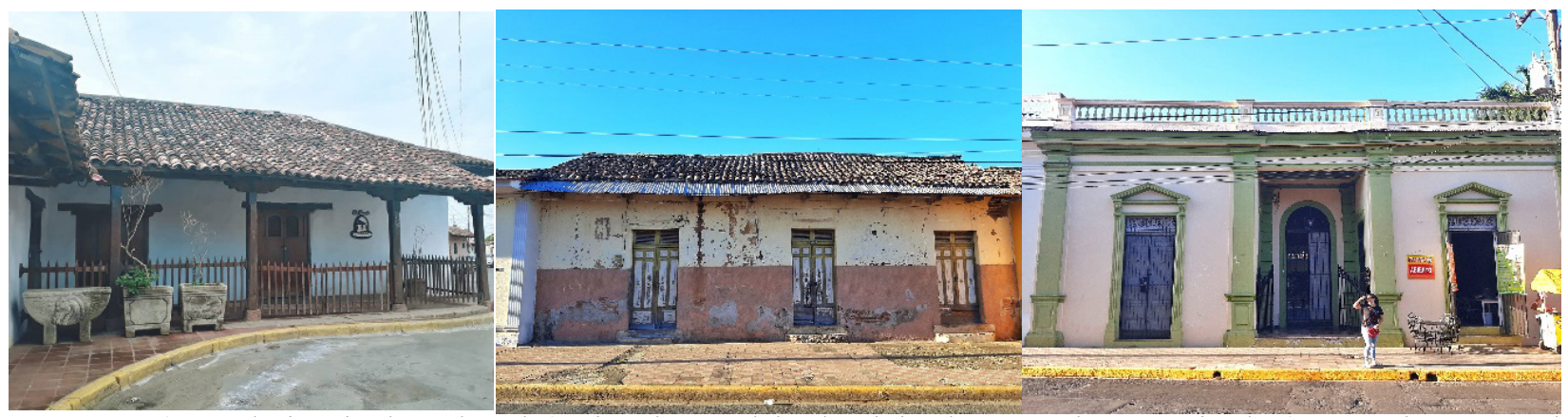

Figura 8: (Leer de izquierda a derecha) Singular modelo de vivienda con galería porticada (Casa Palenque o El Recodo), Arquitectura colonial tradicional dintelada sobre Calle Real Xalteva y Casa neoclásica de un nivel sobre misma calle. Fuente: Propia. 
Tabla 1: Generalidades tipológicas vigentes de la arquitectura colonial domiciliar. Casos de estudio Granada y León.

\begin{tabular}{|c|c|c|c|}
\hline \multicolumn{2}{|c|}{ Elemento } & Granada & León \\
\hline \multirow{7}{*}{ 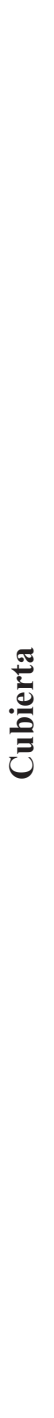 } & \multirow{6}{*}{ 气̊ } & \multicolumn{2}{|c|}{$\begin{array}{l}\text { Pendientes a dos aguas con cubrición de teja de barro. Generalmente una caída hacia el exterior y } \\
\text { la otra hacia un patio interno. }\end{array}$} \\
\hline & & \multicolumn{2}{|c|}{ Cubrición de teja de barro cocido, sostenidas sobre estructura de madera. } \\
\hline & & $\begin{array}{l}\text { Arquitectura neoclásica: Balaustradas en } \\
\text { áticos, a manera de muros culatas ocultan } \\
\text { el tejado. }\end{array}$ & $\begin{array}{l}\text { Arquitectura neoclásica: No se observan a menudo } \\
\text { balaustras. Estas son sustituidas por motivos } \\
\text { geométricos o decoraciones en alto relieve. Modelos } \\
\text { en menor frecuencia respecto a Granada. }\end{array}$ \\
\hline & & $\begin{array}{l}\text { Arquitectura colonial tradicional: } \\
\text { predominio de exposición de canes con } \\
\text { ornamentos que siguen patrones uniformes } \\
\text { en la ciudad. }\end{array}$ & $\begin{array}{l}\text { Arquitectura colonial tradicional: canes, cenefas y } \\
\text { modillones ricamente labrados. Según su Estudio } \\
\text { Tipológico Urbano-Arquitectónico, para el año } \\
2004 \text { se han contabilizado } 21 \text { inmuebles con - } \\
\text { (Oficina Técnica de Gestión del Centro Histórico, } \\
\text { 2010, p. 117). }\end{array}$ \\
\hline & & $\begin{array}{l}\text { Arquitectura colonial popular: canes de } \\
\text { madera pobremente labrados o sin labrar. }\end{array}$ & $\begin{array}{l}\text { Arquitectura colonial popular: Ausencia de cenefas } \\
\text { y todo lo referido a la madera labrada. Canes con } \\
\text { poco ornamento o ausencia de este. }\end{array}$ \\
\hline & & $\begin{array}{l}\text { Predominio de la exposición de los canes y } \\
\text { aleros encañados. }\end{array}$ & $\begin{array}{l}\text { Sus aleros tienden a cubrirse por un cielo falso de } \\
\text { madera labrada rematado al frente por cenefas. } \\
\text { También se observan aleros cubiertos con caña } \\
\text { castilla. }\end{array}$ \\
\hline & $\stackrel{\varrho}{\varrho}$ & $\begin{array}{l}\text { En el interior de las viviendas se suele } \\
\text { observar el techo encañado siguiendo su } \\
\text { pendiente. Existen exponentes de cielos } \\
\text { machimbrados en viviendas de familias } \\
\text { con poder adquisitivo. }\end{array}$ & $\begin{array}{l}\text { Predomina la instalación de cielos suspendidos } \\
\text { de madera labrada. En viviendas coloniales } \\
\text { tradicionales y vernáculas populares se observa el } \\
\text { uso de caña castilla. }\end{array}$ \\
\hline$\stackrel{\varrho}{\stackrel{0}{\Xi}}$ & 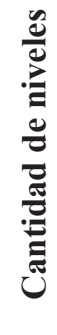 & $\begin{array}{l}\text { Se pueden encontrar inmuebles de uno } \\
\text { y dos niveles con tendencia neoclásica. } \\
\text { Predominio de viviendas de un piso en } \\
\text { la arquitectura colonial tradicional y } \\
\text { vernácula popular. Pocos exponentes de } \\
\text { balcón corrido de madera en viviendas } \\
\text { tradicionales de dos niveles. }\end{array}$ & $\begin{array}{l}\text { Prevalecen inmuebles de un nivel. Pocos exponentes } \\
\text { de arquitectura neoclásica en comparación con la } \\
\text { ciudad de Granada. Predominio de arquitectura } \\
\text { colonial tradicional. Importantes obras de } \\
\text { arquitectura doméstica coloniales vernácula se } \\
\text { ubican en los diversos concejos del territorio de } \\
\text { Sutiava, León. }\end{array}$ \\
\hline
\end{tabular}




\begin{tabular}{|c|c|c|}
\hline Elemento & Granada & León \\
\hline & \multicolumn{2}{|c|}{$\begin{array}{l}\text { Fachadas neoclásicas: incluyen elementos como balaustras en balcones y coronación de muros } \\
\text { simulando áticos, zócalos (estos presentan diferentes acabados y relieves), pilastras adosadas } \\
\text { lisas coronadas con capiteles de reminiscencia clásica, impostas en arcos de accesos y ventanas, } \\
\text { cornisas corridas dividiendo los cuerpos en inmuebles de dos niveles. Se presentan algunos casos } \\
\text { de sillería expuesta o almohadillados en muros. } \\
\text { Determinan la arquitectura con mayor estética de la ciudad de Granada. Exponentes concentrados } \\
\text { a lo largo de Calle Real Xalteva en uno y dos niveles. } \\
\text { En León se comparten las características formales, sin embargo, predominan las viviendas de un } \\
\text { nivel (con excepción del Hotel La Perla). No corresponde a una estilística representativa de la } \\
\text { ciudad. }\end{array}$} \\
\hline 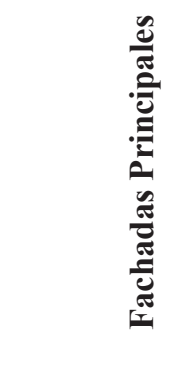 & $\begin{array}{l}\text { Fachadas coloniales tradicionales: aparente } \\
\text { limpieza, molduras generales en vanos de } \\
\text { puertas y ventanas, y representatividad } \\
\text { por escala. Las esquinas con ochave están } \\
\text { decoradas con esmero a través de portales } \\
\text { de reminiscencia clásica, pretendiendo } \\
\text { jerarquizar el acceso. }\end{array}$ & $\begin{array}{l}\text { La belleza de la arquitectura doméstica leonesa } \\
\text { destaca por la jerarquía en escala y altura del } \\
\text { inmueble, potenciada la riqueza de los portales } \\
\text { de sus zaguanes que destacan sobre cualquier } \\
\text { elemento de la fachada, la verticalidad de sus } \\
\text { ventanas con repisas o pata de pollo de sobria } \\
\text { herrería, rica ornamentación del pilar de punta de } \\
\text { lanza, modillones muy trabajados y celajes muy } \\
\text { ornamentados. }\end{array}$ \\
\hline
\end{tabular}

Fachadas coloniales populares: limpieza en fachada, realce por relieve de zócalos y otros en contornos de puertas y ventanas. Vanos de ventanas de proporciones reducidas. Variantes o escasez de la ventana de vasista en puertas.

Esquinas con ochave o chaflán (únicamente se ha documentado un inmueble con una especie de punta de lanza localizada del costado sur de Iglesia La Merced, 1 c. S.

Esquinas con ochave o punta de lanza (siendo la segunda, la que ha generado distinción por su singularidad y ha sido replicada de forma más simple en otras ciudades del occidente del país).

La desmembración de los inmuebles y el notorio cambio de uso de suelo ha generado variedades cromáticas en las fachadas que constituyen las líneas de las manzanas. Estas tonalidades van desde tradicionales amarillo ocre, rojo terracota (muy seleccionado para zócalos y detalles de remates en bordes de puertas y ventanas), azul y blanco con sus derivaciones.
Hasta hace pocos años los colores exteriores se mantuvieron, en el amarillo oscuro, el blanco hueso, el café, el azul, el verde, quizás con el objeto de atenuar el efecto de los rayos solares. Sin embargo, ahora se utiliza una gran variedad de colores y combinaciones, pero siempre manteniendo la costumbre de pintar el zócalo, las puertas y su borde de un color oscuro y las paredes de un color claro (Oficina Técnica de Gestión del Centro Histórico de León, 2010, p. 125).

De doble hoja o una hoja. Tienden a presentar ventanas de vasistas que propician iluminación desde el exterior hacia el ambiente. Este tipo de ventanilla en hojas de puertas son de arco de medio punto en Granada y otras variantes en León.

Celajes para cubrir arcos de medio punto. Se encuentran principalmente en metal y algunos exponentes de madera labrada y manera de celosías.

Predominio de accesos con arcos rebajados en la ciudad de Granada.

En ausencia de vasistas, las hojas se ornamentan únicamente con tableros. 


\begin{tabular}{cl}
\hline Glemento & \multicolumn{1}{c}{ Granada } \\
\hline & $\begin{array}{l}\text { Los zaguanes eran el ingreso de carruajes y carretas de servicio. Formalmente destacan como } \\
\text { portales con motivos que varían en los estilos neoclásicos y barrocos (predominan en la ciudad de }\end{array}$ \\
León). En la arquitectura doméstica neoclásica, predominan accesos dintelados y el zaguán crea \\
una pauta con un arco de medio punto. En el caso del Hotel La Perla de la ciudad de León se han \\
observado arcos de medio punto en primer nivel y segundo lo integran arcos dintelados.
\end{tabular}

Las hojas de las puertas tienen a presentar ventanas de vasistas, también con herrajes con motivos lineales y curvos (volutas que completan diferentes motivos).

En León, el área estimada para patios ocupa una cuarta parte del área total del lote (esto en correspondencia con análisis de inmuebles catalogados como la Casa Salud Debayle y Casa Norberto Ramírez, recopilados en el Estudio Tipológico urbano-Arquitectónico del Centro Histórico de León). En Granada estas relaciones son aproximadas.

León presenta crujías con longitudes promedios de $6 \mathrm{~m}$ de ancho. Por su parte, Granada "se funda en un módulo cuadrangular de aproximadamente $7 \mathrm{~m}$ de lado" (Oficina de Preservación del Centro Histórico de Granada, 2003, p. 11)

Crujías en "L" en casas esquineras y en "C" o "U" y "O" en centros de manzanas.

Proporciones 1:2 entre corredor y crujías.

* Se requiere realizar un estudio detallado, que arroje la media de la longitud predominante de las dependencias de las crujías. Evidentemente, Granada comparte con León la misma tipología de crujías. La mayoría se encuentran alteradas en ambas ciudades, al igual que la reducción de sus patios.

Baldosas tipo mosaico de recapitulación italiana. Su incidencia primeramente fue mayor en Granada debido a la incursión de Mario Favilli y su arquitectura italiana, así como las fábricas artesanales que producían este piso con variedad de motivos florales y geométricos.

Baldosas de cemento en variedad de tonos monocromáticos y manchas.

Baldosas de barro cocido para cubrición en áreas exteriores de patios.

Piedras rectangulares (algunas de tipo basálticas) delimitan el borde de las cunetas y borde de corredores.

Fuente: Elaboración propia a partir de los Planes Tipológicos Urbanos Arquitectónicos de Granada y León. 


\section{Sistemas constructivos tradicionales}

Los materiales y técnicas empleadas en la época precolombina y la virreinal, establecen los primigenios sistemas constructivos adoptados como sociedad y su legado constructivo aplicado en la arquitectura colonial. Estos son muchos y se asocian a tipologías arquitectónicas particulares.

Durante la época prehispánica, los nativos construían sus viviendas con materiales vernáculos, mediante sistemas de horcones de madera para determinar la estructura acompañados de caña y paja como cerramiento. La madera será un material muy utilizado durante la colonia para la construcción de diversas tipologías y tareas de ebanistería que van desde arte sacro hasta doméstico. Arroyo Duarte (2021), hace referencia a los géneros de madera implementados en las construcciones virreinales de Panamá durante los tempranos siglos de ese período: "son muchas las especies que se utilizan en dicha construcción y su mayoría nativas: cedro y cedro espinoso, madera amarilla, guayacán, roble, mangle, níspero, quira, pino, laurel y espavé (AGI Contaduría 1459 y 1465)". Muchos de estos ejemplares también se encuentran en Nicaragua y por ende, sugieren un recurso natural muy explotado.

El historiador, Clemente Guido describe a León Viejo en una época temprana de la siguiente manera: "de 1524 a 1530, una ciudad pequeña, con pobres edificaciones, copias de las chozas indígenas y algunas construcciones mayores como Catedral (en su primera etapa), La Merced y la casa del Gobernador, pero todavía muy rudimentarias" (C. Guido, comunicación personal, 9 de septiembre de 2017).

A partir de 1530, existe evidencia documental del uso del tapial, siendo el sistema predominante en los vestigios arqueológicos de León Viejo. Según Pérez Valle (1993), "se promulgaron cédulas obligando a los encomenderos a construir de piedras o de tapias en los dos primeros años de su encomienda". Por otra parte, el arquitecto, restaurador del sitio arqueológico y exdirector de la Escuela Taller Don Pepe Escudero de León, Eduardo Rodríguez, refiere una clara definición de sus componentes: "sistema tapial, a base de tierra apisonada, revuelta con piedra pómez y arena de río. Va desde el cimiento hasta la pared” (E. Rodríguez, comunicación personal, 3 de octubre 2017).

Por tanto, estos materiales son la base de los sistemas en Nicaragua. Con algunas adaptaciones gracias a las experiencias históricas, mano de obra local, técnicas y normas españolas, marcaron la impronta de los sistemas de adobe, taquezal y albardeado o bahareque en la arquitectura doméstica, respondiendo a condiciones naturales, sociales y económicas de las ciudades indianas. A este grupo de sistemas constructivos es meritorio agregar el material cerámico de ladrillo de barro cocido, cuya evidencia en León Viejo data de 1542, utilizado en tipologías monumentales como "iglesia La Merced, la casa de Hernán Nieto, junto a la misma; la cárcel construida por Contreras" (PérezValle, 1993, p. 32).

\section{El adobe:}

Es la técnica que utiliza tierra cruda para edificar paredes de grandes dimensiones $(0.80$ $1.00 \mathrm{mt}$ de ancho), construidas en bloques mezcla de tierra, arena y fibra vegetal (zacate, fibra de palma, de pita), colocados en hileras alternas horizontales y transversales con repello o revoco, siempre a base de tierra (Palacios García \& Silva Valerio, 2015, p. 13).

- Empleado en León posterior a 1610, año de su traslado a las inmediaciones del pueblo indígena de Sutiava. Aún se requiere mayores indagaciones para la determinación de la introducción de este sistema en Granada. Se asume que fue posterior a 1585, ya que para ese 
año "los edificios son de tapia y techos de teja de barro" (García, 2008, p. 126).

- "El sistema consistió en la elaboración de bloques de barro mezclados con zacate y paja secados al sol, dispuestos uno sobre otros conformando hileras sucesivas" (García, 2008, p. 53). Estas formas de disposición del bloque de adobe corresponden a la técnica de "tizón y soga".

- "Las dimensiones del bloque están relacionadas entre sí 1:2 aproximadamente con valores modulados alrededor de $14.0 \mathrm{~cm}$ " (Oficina Técnica de Gestión del Centro Histórico, 2010, p. 135). El grosor de los muros variaba según la altura de la pared, y por tanto, este es un aspecto definidor de la proporción en estos inmuebles.

- Estructuralmente, la transmisión de cargas se logra a través de los muros y columnas de madera dispuestas sobre zapatas de piedra.

\section{El taquezal:}

Constituido por muros con estructura de madera a base de columnas y vigas con un ancho normalmente de $20 \mathrm{cms}$. Esta estructura inicial se refuerza con reglas de madera en ambos lados, rellenando el interior con mezcla de mortero a base de tierra, talpuja, arena o cal y restos de teja de barro o piedra natural. Se asienta sobre una fundación corrida de piedra, aglomerada con mortero a base de cal, arena y talpuja (Palacios García \& Silva Valerio, 2015, p. 13).

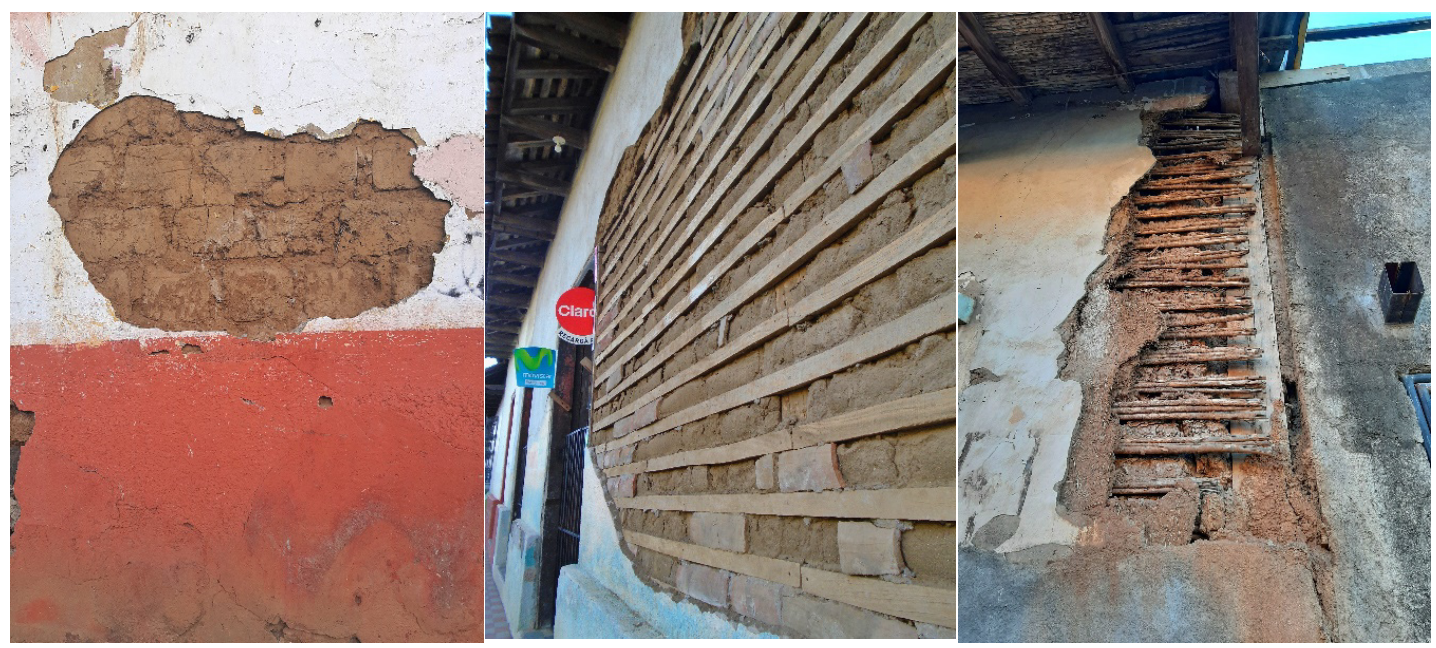

Figura 9. (Leer de izquierda a derecha) Muestra de adobe en el barrio de Sutiava, León. Taquezal expuesto en vivienda del barrio San Felipe, León. Albardeado o bahareque en el área de transición del Centro Histórico de Granada. Fuente: elaboración propia.

- Este sistema es posterior al adobe, seleccionado para la construcción de viviendas de una y dos plantas. En el último caso, sus escaleras y entrepisos eran de madera. Sin embargo, existen excepciones como la Casa Sampieri en Granada, en la cual existe una escalera de mármol, la cual puede obedecer a un momento evolutivo de la constitución del inmueble.

- El henchido o material de relleno presenta variantes. En Granada se han encontrado rellenos a base de tierra, otro material orgánico (zacate) y teja de barro. En León se han observado modelos con rellenos de piedra. 
- La madera garantiza la estabilidad de los muros, al igual que el peso gravitacional que le proporciona el henchido (Oficina Técnica de Gestión del Centro Histórico, 2010, p. 136).

- La cubrición de los aparejos, (de cal y arena) eran muy importantes para garantizar el estado de conservación de este sistema, así como la calidad y condición de la madera. Este enlucido debía contener integrantes compatibles con el del henchido.

- Al igual que en el adobe, los cimientos pétreos aportaban al aislamiento de los muros orgánicos con la humedad del suelo. La profundidad del cimiento recomendada es al menos un décimo de la altura del muro.

\section{Albardeado o bahareque:}

Es conformado por una estructura de madera sencilla, caña o reglillas, y columnas rústicas de madera. Las paredes constituyen la mezcla de tierra con zacate picado, que se aplica a mano sobre las dos caras de la estructura, sobresaliendo en relieve las columnas de madera. En este caso, la tierra hace función de relleno, aplicada en forma de mortero (Palacios García \& Silva Valerio, 2015, p. 14).

- Este sistema muy similar al taquezal, pero con reducción de la sección de muros e introducción de material ripio.

- Generalmente su estructura está compuesta por columnas de madera al igual que el taquezal y el enchido, pero con cerramiento a base de caña castilla.

- Composición paño-vano-paño, con escases de aperturas para ventanas.

- Supuso el sistema constructivo de las periferias de los centros históricos, hoy áreas de transición.

\section{Ladrillo de barro cocido. Ceballos Espigares (2018) comenta al respecto:}

Situado también en este grupo (materiales pétreos artificiales), pertenece a la rama de la tejería o de los productos cerámicos que adquieren consistencia por procesos físicos como la cocción. Es una masa de arcilla cocida, en forma de paralelepípedo rectangular, que posee destacadas cualidades de resistencia, rigidez y duración.

- El vecino español Hernán Nieto fue el primer ciudadano en tener horno en la ciudad de León Viejo. Pérez-Valle señala que este personaje fabricaba tejas y ladrillo. A estos productos se debe agregar las baldosas por su existencia arqueológica en el sitio. En la casa de Gonzalo Cano de León se encontraron baldosas que revisten el piso al estilo romano "espina de pez". Si bien, en ese momento el ladrillo no fue implementado para originar una variante de mampostería, fue de utilidad exclusivamente para elaborar las columnas y arcos de la iglesia La Merced, adherido probable con argamasa a base de cal, arena y arcilla talpuja. A pesar de constituir un material resistente al fuego, su producción demandaba elevados costos. Por tanto, el ladrillo de barro fue un importante aporte para los modelos constructivos para León en su segundo lugar de asentamiento, Granada y otras ciudades indianas.

- En 1585 se hace referencia al uso de la teja en Granada. "Los edificios son de tapia y techos de teja de barro" (García, 2008, p. 126).

- A lo largo de la vida de las ciudades de Granada y León se ha utilizado en viviendas 
como un material auxiliar, mediante el reforzamiento de estructuras, muros paralelos en zonas húmedas y zócalos, debido a sus propiedades de compatibilidad con los sistemas orgánicos y aislante de humedad. Su posterior relativo bajo costo propició su preferencia en la mampostería confinada (horcones de madera y posteriormente columnas de acero y concreto) en viviendas populares en diferentes ciudades del país.

- El arquitecto, Eduardo Rodríguezargumenta que León en su segundo lugar de establecimiento, contó con un horno próximo a la zona llamada "Hoyo de la Campana" en el barrio Zaragoza. Asimismo, brinda un importante aporte sobre los métodos constructivos tradicionales: "tanto el ladrillo, la piedra cantera y el bloque de adobe, basaron su técnica en la mampostería de hiladas a soga y tizón” (E. Rodríguez, comunicación personal, 26 de febrero de 2021).

- Actualmente, los mayores productores de este material en variedades de ladrillos para muros, pozos artesanales, pisos, fachaletas y tejas, se localizan en el municipio de La Paz Centro del departamento de León.

\section{Piedra de cantería:}

El material pétreo era obtenido en las minas de canteras cercanas a estas ciudades. En el caso de Granada se hace una representativa referencia al Cerro Posintepe, localizado al sur de esta. Respecto a León, el arquitecto Eduardo Rodríguez aporta que este importante recurso de composición arenisca sedimentaria era extraído mayoritariamente de la ribera del Río Chiquito (E. Rodríguez, comunicación personal, 26 de febrero de 2021).

Según el Estudio Tipológico Urbano Arquitectónico de Granada, el adobe lideraba su uso en los sistemas constructivos con el $31.28 \%$ que equivale a 418 inmuebles (se incluyen todas las tipologías arquitectónicas) y un $16.92 \%$ lo ocupa el taquezal equivalente a 226 edificaciones. Respecto a cubierta, predominaba el 77.32\% que corresponde a 1033 inmuebles (Oficina de Preservación del Centro Histórico de Granada, 2006, p. 124).

En León, “el 60\% de la edificación leonesa conserva los sistemas constructivos tradicionales: adobe, taquezal, piedra y madera". El primero ocupa el $45.4 \%$ que corresponde a 1121 inmuebles y el segundo, $14.1 \%$ que equivale a 348 edificaciones. "Además dentro del sistema constructivo mixto, la gran mayoría corresponde a inmuebles que presentan, en fachada, adobe y taquezal o adobe y mampostería" (Oficina Técnica de Gestión del Centro Histórico, 2010, p. 138).

\section{Los valores culturales en el patrimonio}

Las posturas sobre la definición y categorías del patrimonio cultural han evolucionado en el siglo pasado, propiciando nuevas teorías inclusivas sobre la diversidad cultural y patrimonial, abandonando el anterior discurso del patrimonio cultural vinculado exclusiva y férreamente al monumento. Esto respalda la importancia del reconocimiento de un sistema de valores culturales vinculados al patrimonio cultural, debido a los atributos que identifican a un colectivo en aspectos materiales e inmateriales de sus vidas, y tal relevancia supone una voluntad de traspaso de estas características singulares a las futuras generaciones.

Entre el conjunto de esfuerzos internacionales por la conservación y salvaguarda del patrimonio cultural y natural, figura la Convención de Nara. Celebrada en Japón en 1994, dio origen a un instrumento conocido como Carta de Nara, cuyo propósito es la superación de los retos en la conservación, aceptando la relevancia de la memoria colectiva de los pueblos como un factor identitario con un sistema de valores culturales que son amenazados por las demandas de una 
sociedad globalizante. Ante estos retos, es imprescindible el reconocimiento de la significación cultural, como el cúmulo de valores culturales (estéticos, históricos, científicos, sociales, espirituales, entre otros) que propician la identidad colectiva.

La Carta de Nara en el punto 13, hace referencia a la autenticidad. Junto a la significación, constituyen componentes de valoración del patrimonio cultural y su conservación, justamente por el carácter de singularidad:

Dependiendo de la naturaleza del patrimonio cultural, de su contexto cultural, y de su evolución a través del tiempo, los juicios de autenticidad pueden vincularse al valor de una gran variedad de fuentes de información. Algunos de los aspectos de las fuentes pueden ser la forma y el diseño, los materiales y la sustancia, el uso y la función, la tradición y las técnicas, la ubicación y el entorno, así como el espíritu y sentimiento, y otros factores internos y externos. La utilización de estas fuentes brinda la posibilidad de analizar el patrimonio cultural en sus dimensiones específicas en los planos artístico, técnico, histórico y social (Conferencia Nara, 1994).

Estas fuentes engloban las categorías del patrimonio cultural: material e inmaterial. El primer grupo sugiere bienes inmuebles, muebles y documentales. El segundo se refiere al patrimonio vivo o cultura viva: tradiciones y expresiones, usos sociales, rituales y actos festivos (juegos tradicionales, bailes y danzas, prácticas musicales y sonoras, artes corporales y celebraciones $\mathrm{y}$ fiestas populares); y conocimientos y usos relacionados con la naturaleza y el universo (medicinas tradicionales, cosmologías, organizaciones sociales, sistemas alimentarios y técnicas y conocimientos productivos) (Campos Berkhoff, 2014, p. 12).

Ambas categorías deben coexistir, ya que es el sujeto quien produce patrimonio y es a quien corresponde valorarlo. La reciprocidad entre el patrimonio tangible e intangible (como también se le conoce) referidos a los sistemas constructivos tradicionales, está dado por la aplicación de un conocimiento que generó un oficio como parte del tequio prehispánico y posteriormente tequio virreinal. Esta tarea y forma de vida fue relevante para el desarrollo de la sociedad, ya que los alarifes, albañiles y otras ocupaciones derivadas fueron las responsables de suplir una necesidad primordial y un derecho humano materializado en la vivienda.

Esto constituye un valor social, con énfasis tecnológico-popular, ya que los principios de urbanismo y de construcción como la introducción del sistema de medición de la vara castellana, correspondieron a la necesidad de implantar inmuebles para los vecinos españoles como componente de la estructura urbana de las nuevas ciudades, junto a la evolución de las técnicas y tradiciones de edificación de nuestros nativos que conformaron a posteridad los sistemas constructivos mestizos de la naciente sociedad nicaragüense.

Otro agente que coadyuvó en la implantación de estos valores fue la formación profesional y destreza, ya que es evidente que se requirió preparación de mano de obra que adquiriera competencias en la preparación y manejo de la cal, así como en el reconocimiento de materias primas adecuadas con propiedades de cohesión interna de la arcilla al actuar como aglutinante natural para la elaboración de bloques de adobe. Además de la cal y tierra, se necesitaron gremios en el oficio de la cantería, carpintería, herrería y artesanía en horno para el caso de la producción de materiales de barro cocido como la cotizada teja criolla.

Ante el sinnúmero de exponentes de arquitectura habitacional con tendencia colonial aún existentes, se puede considerar que las fuentes relacionadas a los sistemas constructivos tradicionales que han sufrido destrucción total o parcial por motivos bélicos y naturales en los 
siglos pasados, fueron reaprendidas y nuevamente implantadas $\mathrm{y}$, por tanto, no constituyen un símbolo de renuncia a la prosperidad. Las destrucciones y reconstrucciones en las ciudades de León y sobretodo Granada, han evidenciado la resiliencia de estos centros urbanos al demostrar su impronta en la adopción de elementos que han definido las particularidades en su arquitectura y por supuesto, en sus técnicas constructivas por saberes tradicionales que partieron de técnicas ancestrales y las incursiones tecnológicas heredadas de España.

Esta misma carta en su Apéndice 1. Punto 1, reconoce: "el respeto a la diversidad cultural y al patrimonio requiere esfuerzos conscientes para evitar la imposición de fórmulas mecánicas o procedimientos estandarizados en el intento por definir o determinar la autenticidad de determinados monumentos o sitios" (Conferencia Nara, 1994). Notoriamente, el patrimonio cultural no se limita a nuestro pasado, es testimonio de la evolución de los sistemas constructivos tradiciones y da cabida a otras etapas históricas que han aportado nuevos estilos como la arquitectura historicista y la contemporánea, así como nuevos sistemas basados en el acero y concreto introducidos a mitad de siglo pasado. No obstante, las acciones de vinculación entre los sistemas viejos y los nuevos han resultado en problemas de incompatibilidad que menoscaban el patrimonio cultural de la arquitectura de tierra, y que actualmente constituyen una de las principales amenazas por acción antrópica referida a intervenciones inadecuadas por omisión, desconocimiento, mano de obra no calificada que se suma a los intereses personales de herederos e inversionistas no concientizados. Esta realidad merece ser objeto de estudio particular, ya que atentan contra los valores generales del patrimonio cultural en las ciudades con rasgos virreinales.

Vinculado al bien común y la sostenibilidad, el patrimonio cultural debe considerarse agente de desarrollo. Es aquí donde surgen las escuelas de oficio, luego reconocidas como escuelas taller, fundadas en las ciudades de León, Granada, Masaya, Chinandega, Rivas, Ocotal, Somoto, Ometepe, Región Autónoma Atlántica Norte y Acahualinca en Managua, como parte del Programa Patrimonio para el Desarrollo de la Agencia Española de Cooperación Internacional para el Desarrollo (AECID-Nicaragua). Estas aportaron tecnificación de jóvenes y su ingreso al mercado laboral, mediante el fortalecimiento del sistema público de capacitación laboral en los oficios tradicionales (entre estos la construcción) y en otros con proyección en el desarrollo local de cada comunidad bajo la estrategia educativa aprender-haciendo (AECID-Nicaragua, 2011, p. 291).

El arquitecto, Eduardo Rodríguez exdirector de la Escuela Taller Don Pepe Escudero de León entre los meses de enero a junio de 1997, expone que las líneas educativas estuvieron dirigidas a:

- Formación Teórica General. Relacionado a la enseñanza del español y matemáticas.

- Formación Técnica Especializada. Enseñanza aprendizaje sobre los oficios de albañilería, carpintería, electricidad, fontanería, herrería, jardinería y pintura. Todo de cara a formar un técnico de la construcción en esta área. En los talleres se esbozan recreaciones didácticas de todas las especialidades, pero en ese momento no había una sobre restauración sobre sistemas tradicionales.

- Formación Técnica Complementaria. Enseñanza aprendizaje sobre dibujo arquitectónico, Gestión Socio Laboral e Historia del Arte y la Arquitectura. Esta última se preparaba en temas sobre estilos arquitectónicos, teoría del centro histórico de la ciudad, leyes del patrimonio histórico y cultural, y urbanismo (E. Rodríguez, comunicación personal, 26 de febrero de 2021).

Según otra fuente vinculada al mismo proyecto, en la Escuela Taller de León, en el año 1994 
se impartieron capacitaciones relacionadas a "Restauración-Rehabilitación, Patologías en la Restauración, y por tanto Técnicas de Construcción con Tierra" (E. Rodríguez, comunicación personal, 26 de febrero de 2021).

Las escuelas taller fueron una iniciativa contemporánea de salvaguarda de la práctica de construcciones tradicionales vinculada con la dotación de habilidades y destrezas en los jóvenes de limitados recursos económicos, conformaciones gremiales y divulgación del patrimonio cultural, ya que la educación a través del conocimiento y las vivencias son una forma de propiciar la sensibilización del patrimonio cultural, tan importante para dar lugar al origen y fortalecimientos de valores culturales, y sobretodo el sentido de identidad.

Actualmente, existen esfuerzos del Estado sobre la documentación y caracterización de los sistemas constructivos tradiciones en estudios tipológicos de León y Granada, catálogos de bienes patrimoniales en la región del Pacífico, pequeños manuales de cómo tratar los sistemas constructivos principales como el adobe y taquezal en las oficinas de Centros Históricos de las ciudades de León y Granada, textos sobre los monumentos y sus valores culturales-patrimoniales, cuadernillo comunitario "¿Cómo conservar nuestras casas y edificios antiguos?", entre otros recursos elaborados por el Instituto Nicaragüense de Cultural (INC).

\section{Conclusiones}

Existen similitudes y a la vez diferencias marcadas en las características tipológicas de la vivienda virreinal de las ciudades de León y Granada. Estas particularidades de la envolvente se van perfeccionando según el desarrollo de cada ciudad, pero comparten la materia del contenedor: sistemas constructivos tradicionales. Aún quedan pocos exponentes del balcón corrido en León y existe un predominio de inmuebles con esquinas con punta de lanzas. En Granada totalmente figura la esquina en ochave y sus exponentes neoclásicos son más ricos.

Respecto a los modelos, a pesar de la densificación de parcelas por el crecimiento poblacional y las nuevas necesidades de los ocupantes, aún se logra leer la tipología de crujías o alas en torno a patios como herencia de las células domésticas iniciales. No obstante, a partir del siglo XX se han alterado gradualmente sus espacios y fachadas principales. Entre las modificaciones figuran la ocupación en el post-patio, construcciones de piscinas en patio central debido a los cambios de usos de viviendas a hoteles, reducción de las crujías por instalaciones de baños en dependencias que no los tenían, entre otras. En fachadas se observan rompimiento de la línea, la cual aportaba el principio de continuidad en las manzanas, ruptura de vanos para crear ventanas, ensanchamiento del acceso del zaguán para dar lugar a los medios de transportes contemporáneos en lugar de la carreta, entre otros.

Los sistemas constructivos predominantes son el adobe, taquezal, albardeado o bahareque (en este último sobreviven pocos inmuebles por su menor calidad respecto a los anteriores), la cantera usada en cimientos, zócalos, vanos y bordes de aceras, baldosas de cemento y el ladrillo de barro cocido y sus variantes. Este conjunto ha permanecido en el tiempo, por tanto, han ocupado un lugar en la historia de la sociedad nicaragüense y deben ser conservados. Otro aporte es el referido a la introducción de la vara castellana como sistema de medición en construcción, aún utilizado por maestros de obras y albañiles a pesar de no constituir el sistema métrico decimal.

El reconocimiento de los valores culturales de la tipología habitacional conlleva a la apreciación del patrimonio cultural inmueble y es el resultado de la sensibilización patrimonial. Los valores inmersos en la arquitectura doméstica producto de la época virreinal en Nicaragua, engloba 
elementos singulares para la región iberoamericana y obedece al hibridismo de dos raíces culturales: española y nativa. Solo el trabajo en colectivo de diferentes sectores coloniales, pudo generar la conformación y evolución de la arquitectura habitacional, hasta heredar los modelos de viviendas que hoy destacan en los centros históricos de Nicaragua y sus exponentes aislados.

\section{Recomendaciones}

- Es necesario realizar estudios de la vivienda rural colonial, así como los modelos tradicionales de villas coloniales y ciudades menos relevantes, ya que también integran este acervo cultural inmobiliario.

- Es imprescindible el ejercicio de la concienciación en materia de conservación de inmuebles con sistemas tradicionales dirigida a diferentes sectores de la sociedad, principalmente propietarios e inversionistas.

- El Estado, gobierno local, universidades y escuelas de oficios contemporáneas deben interiorizar en el estudio de las propiedades de los sistemas constructivos vernáculos y retomar la formación académica de estos, así como su tratamiento bajo estrategias de aprendizaje teóricas-prácticas.

- Luego de la formación de profesionales y mano de obra, es sustancial normar en el Reglamento Nacional de la Construcción (RNC) y otras leyes, estos sistemas que han sido muy criticados a raíz de los terremotos ocurridos en Managua en el siglo pasado, pero que aún constituyen un representativo porcentaje de edificaciones a nivel nacional.

- En las ciudades con centros históricos con marco legal establecido como León y Granada, es menester la consolidación del personal técnico que permita dar seguimiento a los proyectos autorizados y a la detección de intervenciones irregulares e inadecuadas. Asimismo, establecer nuevas áreas de protección en ciudades con atributos coloniales y que se encuentren sin protección.

\section{Referencias}

Aguilera Rojas, J. (1994). Fundación de ciudades hispanoamericanas. MAPFRE.

Arroyo Duarte, S. (2021). Actores, materiales y tecnologías en la construcción de Casas Reales de Panamá en los siglos XVI a XVII. Primer Coloquio Internacional Virtual «La casa de Deán D. Tomás de la Plaza. Contextos y herencias culturales entre el Viejo y Nuevo Mundo, s. XVI.

Campos Berkhoff, D. (2014). Identificación de Patrimonio Cultural Inmaterial. Herramientas para la Gestión Cultural Local. Consejo Nacional de la Cultura y las Artes del Gobierno de Chile.

Ceballos Espigares, M. (2018). Estilos y tipologías. Intervención en el Patrimonio Urbano Histórico Colonial. Maestria Centroamericana en Conservación y Gestión del Patrimonio Cultural para el Desarrollo.

Ceballos Espigares, M. (2018). Los materiales y los sistemas constructivos. Maestría Centroamericana en Conservación y Gestión del Patrimonio Cultural para el Desarrollo.

Conferencia Nara. (1994). Carta de Nara. Documento de Nara sobre autenticidad. ICOMOS.

Fernández Vega, P. Á. (2003). La casa romana. Akal. 
García, H. (2008). Granada: historia y desarrollo urbano (segunda ed.). (O. T. Centro, Ed.) Nicaragua: Alcaldía Municipal de Granada.

Instituto Nicaragüense de Cultura [INC]. (2014). León de Nagrando, Origen y Actualidad. Instituto Nicaragüense de Cultura.

Kubler, G. (1982). Arquitectura mexicana del Siglo XVI. Fondo de Cultura Económica.

La Orden Miracle, E. (1971). Catálogo Provisional del Patrimonio Histórico-Artístico de Nicaragua. Comisión Nacional del Sesquicentenario de la Independiencia de Centroamérica en Managua.

Oficina de Preservación del Centro Histórico de Granada. (2006). Estudio Tipológico Urbano Arquitectónico de Granada, Nicaragua. Agencia de Cooperación Internacional al Desarrollo (AECID).

Oficina de Preservación del Centro Histórico de Granada, N. (2003). Resumen Ejecutivo del Plan de Revitalización del Centro Histórico de Granada. Granada: Agencia Española de Cooperación Internacional al Desarrollo (AECID).

Oficina Técnica de Gestión del Centro Histórico de León. (2010). Estudio Tipológico Urbano Arquitectónico del Centro Histórico de León. Alcaldía Municipal de León y Agencia Española de Cooperación Internacional al Desarrollo (AECID).

Palacios García, A., \& Silva Valerio, N. (2015). Cuaderno Comunitario ¿Cómo conservar nuestras casas y edificios antiguos?. Instituto Nicaragüense de Cultura-UNESCO.

Pérez-Valle, E. (1993). Esas son las ruinas de León Viejo. En León Viejo: Pompeya de América. Instituto Nicaragüense de Cultura.

Programa Patrimonio para el Desarrollo, AECID-Nicaragua. (2011). Programa Patrimonio para el Desarrollo, AECID. 20 años con Nicaragua. Agencia Española de Cooperación Internacional para el Desarrollo (AECID). 